\title{
KOSZTY KRYZYSU GOSPODARCZEGO W EUROPIE NA TLE INNYCH REGIONÓW ŚWIATA - ANALIZA PRZEKROJOWA ${ }^{2}$
}

\begin{abstract}
Streszczenie
Celem niniejszego opracowania jest prezentacja wyników wstępnej analizy porównawczej skutków kryzysu 2008-2009 w odniesieniu do krajów Europy na tle innych regionów świata. Skutki te są tu rozumiane jako makroekonomiczne „koszty kryzysu”. Makroekonomiczne koszty globalnego kryzysu finansowego oszacowano wykorzystując wybrane dane dotyczące wzrostu gospodarczego w stosunku do wszystkich analizowanych gospodarek. Wyboru metody szacunku dokonano na podstawie przeglądu literatury. W części empirycznej obliczono koszty kryzysu związane z produktem krajowym, wartością dodaną w przekroju grup krajów europejskich, a także w przekroju regionów świata (dla porównania sytuacji w Europie z resztą świata). Następnie policzono koszty dla składowych PKB, jak również dla poszczególnych gałęzi gospodarki i porównano je między grupami krajów.

Przeprowadzona analiza pokazuje, że gospodarka europejska (zwłaszcza Unii Europejskiej i strefy euro) została szczególnie silnie - na tle innych rynków światowych - dotknięta skutkami ostatniego kryzysu globalnego. W sferze eksportu najmocniej obją on kraje Azji Płd. -Wsch. (w tym: Chiny i Japonia), a przyczyna tego był spadek popytu w krajach zachodnich (Unia Europejska, Stany Zjednoczone). Analiza struktury spadków w międzynarodowej wymianie handlowej w podziale na gałęzie gospodarki dowodzi, że stosunkowo największe koszty poniosły przy tym (zarówno w rolnictwie, przemyśle przetwórczym i wydobywczym, jak i w branżach usługowych) kraje bałtyckie i kraje zaliczone w tym badaniu do „nowo przyjętych do strefy euro".
\end{abstract}

Słowa kluczowe: kryzys globalny, koszty kryzysu, badania ilościowe

\section{MACROECONOMIC COSTS OF GLOBAL FINANCIAL CRISIS IN EUROPE AND OTHER REGIONS: A COMPARATIVE ANALYSIS}

\section{Summary}

The aim of the paper is to present the results of a comparative analysis of the macroeconomic consequences of the 2008-2009 global financial crisis in the European countries and other regions of the world. The consequences are understood here as the 'costs of the crisis.' The macroeconomic costs of the crisis have been estimated using data on GDP per capita, GNP and aggregated value added for all the analysed 81 countries. The choice of the estimation method resulted from studies on the research techniques implemented by other authors, both Polish and foreign, interested in the problem. The empirical part of the paper

1 dr Agnieszka Domańska - Instytut Studiów Międzynarodowych, Szkoła Główna Handlowa w Warszawie; e-mail: az.domanska@gmail.com; dr Dobromił Serwa - Instytut Ekonometrii, Szkoła Główna Handlowaw Warszawie; e-mail: dserwa@sgh.waw.pl.

${ }^{2}$ Badania do artykułu zostały dofinansowane przez Narodowe Centrum Nauki w ramach grantu badawczego do wniosku nr N N112 377940. 
estimates and analyses the costs of the crisis in individual economies, in some groups of countries in Europe and other parts of the world, as well as in globally important economies (USA, Japan, NAFTA, South America, South-East Asia, ASEAN countries etc.). A similar analysis has been carried out on components of GDP (consumption, investments, government purchases and net export) and in a cross-sectional (crossindustry) perspective.

The study reveals that the European economy as a whole (and in particular the EU and euro area countries), as compared with other regions/world markets, has suffered especially severe consequences of the world crisis. Analysis of the 'structure' of declines in Europe in a cross-industry perspective shows that the economies most affected by the crisis include the Baltic countries and the 'newcomers' to euro area, particularly in manufacturing, mining and service industries.

Key words: international economy, global crisis, costs of the crisis

\section{Wstęp}

Problematyka skutków globalnego kryzysu gospodarczego lat 2008-2009 została poddana wnikliwej analizie w literaturze naukowej, zarówno zagranicznej, jak i polskiej. Mimo obfitości pozycji na temat kryzysu w ogóle, brakuje w polskim piśmiennictwie ekonomicznym opracowań, które dotyczyłyby stricte makroekonomicznych kosztów kryzysu (tak jak rozumie je literatura przedmiotu), wyliczanych według określonych metod analizy ilościowej. Niniejszy artykuł wypełnia tę lukę.

Celem opracowania jest prezentacja wyników wstępnej analizy porównawczej skutków kryzysu lat 2008-2009 dla krajów Europy, które tu są rozumiane jako „koszty kryzysu"- liczone metodami ekonometrycznymi, dobranymi na podstawie przegladu literatury przedmiotu. Analiza została wykonana w ramach szerszego projektu badawczego pt.: Miedzynarodowa transmisja szokón a podatnośc gospodarek krajón Europy na skutki globalnego kryyzysu gospodarczego 2007-2009. W części empirycznej dokonano obliczeń kosztów kryzysu w odniesieniu do: produktu krajowego, wartości dodanej w przekroju grup krajów europejskich (Unia Europejska, kraje strefy euro, Europa Płd. i Wsch., w niektórych obliczeniach także kraje zaliczone do wyodrębnionej tu grupy „,nowo przyjętych do strefy euro", tj. po 1 stycznia 2007 roku, kraje bogate, poza Unią Europejska, tj. Szwajcaria i Norwegia, kraje bałtyckie, skandynawskie), a także w przekroju regionów świata (dla porównania sytuacji w Europie z resztą świata). Policzono również koszty dla składowych PKB (konsumpcja, wydatki rządowe, inwestycje, eksport netto) i porównano je między grupami krajów (w ramach Europy oraz Europy na tle reszty świata). Szczególną uwage poświęcono spadkom odnotowanym w handlu zagranicznym. Następnie oszacowano koszty dla poszczególnych gałęzi gospodarki (podstawowy podział na branże, tj.: rolnictwo, przemysł wydobywczy, przemysł przetwórczy, budownictwo, handel, transport), dokonując podobnych zestawień. 


\section{Koszty kryzysów - przegląd badań jako podstawa wyboru metody analizy empirycznej}

W badaniach, analizujących koszty makroekonomiczne kryzysów finansowych, często porównywano poziom produktu krajowego brutto (PKB, zwykle w ujęciu realnym liczonym per capita) w czasie kryzysu z hipotetycznym poziomem PKB, jaki zostałby osiagnięty, gdyby kryzys nie nastapił. Analogicznym sposobem liczenia kosztów było porównywanie tempa wzrostu PKB w czasie kryzysu i hipotetycznego tempa wzrostu PKB, gdyby kryzys nie nastapił. Analizy tempa wzrostu PKB przeprowadzili między innymi: MFW [MFW, 1998; MFW, 1999], Azis i inni [Currency Crises..., 2000], Barro [Barro, 2001], Hutchison i Noy [How Bad are..., 2005], natomiast poziomy produkcji porównywali między innymi Hoggarth i inni [Costs of Banking System..., 2002], Boyd $\mathrm{i}$ inni [The Real Output Losses..., 2005], Laeven i Palencia [Banking Crisis Database..., 2010]. Boyd i inni [The Real Output Losses..., 2005] przeprowadzili także dyskusję na temat metod obliczania kosztów kryzysów i zauważyli, że porównywanie tempa wzrostu PKB ma tę wadę, że dynamika PKB może po kryzysie powrócić szybko do swojego trendu sprzed kryzysu, podczas gdy poziom PKB pozostanie na znacznie niższym poziomie niż przed kryzysem. MFW [MFW, 1998; MFW, 1999], Azis i inni badacze dodatkowo sumowali koszty kryzysów z poszczególnych lat, żeby wyliczyć całkowite koszty kryzysów. Dodawali oni różnice między rzeczywistym poziomem (lub dynamika) produktu i hipotetycznym poziomem (lub dynamika) produktu z każdego roku trwania kryzysu lub z każdego roku po wystąpieniu kryzysu, kiedy te różnice były ujemne.

W niniejszym badaniu makroekonomiczne koszty globalnego kryzysu finansowego oszacowano wykorzystując dane dotyczące: produktu krajowego brutto, produktu krajowego brutto (PKB) per capita, produktu narodowego brutto (PNB) w przeliczeniu na dolary amerykańskie oraz wartości dodanej brutto dla wszystkich analizowanych gospodarek. W każdym przypadku analizowano realne zmiany poszczególnych wielkości makroekonomicznych. Liczenia kosztów kryzysu dokonano dzięki zastosowaniu dwóch metod. Według pierwszej - policzono teoretyczny poziom produkcji (lub innej zmiennej) dla każdego z lat: 2008 i 2009 poprzez pomnożenie rzeczywistej produkcji odpowiednio w roku 2007 i 2008 przez średni roczny wzrost z ostatnich 10 lat.

Teoretyczny długoterminowy poziom produkcji wyliczono więc przy użyciu następującego wzoru:

$$
Y_{i t}^{*}=\left\{\begin{array}{ccc}
Y_{i t} & \text { dla } & t<2008 \\
Y_{i t-1}^{*} \cdot\left(\frac{Y_{i, 2007}}{Y_{i, 1998}}\right)^{\frac{1}{10}} & \text { dla } & t \geq 2008 .
\end{array}\right.
$$

Sam koszt kryzysu to procentowe odchylenie policzonej, jak podano wyżej, produkcji teoretycznej od produkcji rzeczywistej odpowiednio w roku 2008 i 2009, a koszt zakumulowany to suma kosztów dla tych lat.

W celu wyliczenia spadku produkcji $\mathrm{w} i$-tym kraju (sektorze, gałęzi gospodarki etc.) rzeczywisty poziom produktu (lub innej zmiennej) $Y_{i t}$ w danym kraju $i$ w okresie $t$ trwania kryzysu porównano więc $z$ teoretycznym poziomem produkcji $Y_{i t}^{*}$, wynikającym 
z długoterminowego trendu produkcji sprzed kryzysu na bazie poniższego wzoru (wielkość spadku produkcji jest wtedy mierzona w ujęciu procentowym):

$$
\Delta y_{i t}=\frac{Y_{i t}-Y_{i t}^{*}}{Y_{i t}^{*}} \cdot 100 \%, \quad \text { dla } t=2008,2009 .
$$

Skumulowany spadek produkcji w całym okresie kryzysu policzono sumując spadki z kolejnych okresów trwania kryzysu. Na przykład skumulowany spadek produkcji w $i$-tej gałęzi gospodarki w latach 2008 i 2009 wynosi:

$$
S_{i}=\sum_{t=2008}^{2009} \Delta y_{i t} .
$$

W metodzie drugiej teoretyczny poziom produkcji (lub innej zmiennej, ti.: poziom konsumpcji, wydatki rządowe, produkcja w danej gałęzi etc.) dla roku 2008 policzono identycznie jak w metodzie 1., zaś dla roku 2009 - poprzez pomnożenie teoretycznej (a nie jak w metodzie 1. - rzeczywistej) produkcji w 2008 roku. Podobnie jak w metodzie 1., koszt kryzysu dla roku 2008 to procentowe odchylenie produkcji teoretycznej od produkcji rzeczywistej w 2008. Natomiast koszt kryzysu dla lat 2008-2009 to procentowe odchylenie produkcji teoretycznej w 2009 roku od produkcji rzeczywistej w 2009, co stanowi już skumulowane odchylenie za dwa lata. Koszty kryzysu, liczone według obydwu metod, są bardzo zbliżone.

Takie samo podejście zastosowano w odniesieniu do spadków w zakresie składowych PKB: wydatków konsumpcyjnych, inwestycji, wydatków rządowych i eksportu netto jako kosztów kryzysu oraz przy liczeniu spadków w przekroju branż gospodarki (w podziale na główne gałęzie, tj.: rolnictwo, przemysł przetwórczy, budownictwo, usługi itd.). Metoda porównania spadku produkcji w poszczególnych branżach między krajami w czasie kryzysu polegała na obliczeniu skumulowanego spadku produkcji w każdej branży i stwierdzeniu, jak kształtowały się one w przekroju krajów (grup krajów) oraz branż. Efektem przeprowadzenia oszacowania modeli o powyższej specyfikacji jest szczegółowa analiza uzyskanych rezultatów i obszerny ich opis. Autorzy próbowali również wyciagnąć wnioski co do ewentualnych podobieństw między krajami w zakresie zbliżonej skali strat w danych rodzajach wydatków, tj. składowych PKB.

\section{Koszty kryzysu w latach $2008-2009$ w Europie i w innych regionach świata - badanie empiryczne}

W pierwszym kroku niniejszej analizy autorzy zmierzali do pokazania skutków kryzysu (na podstawie danych na temat: PKB, PKB per capita, PNB oraz wartości dodanej brutto) ogólnie dla krajów europejskich na tle innych (wybranych) krajów świata z różnych regionów ekonomicznych i wyciagnięcia porównawczych wniosków. W tej wstępnej analizie uwzględniono 81 krajów rozwiniętych i rozwijających się. Wyniki dla każdego kraju oddzielnie przedstawiono w tabeli 1. Dla wszystkich 81 krajów zebrano dane dotyczące PKB. Dla 16 krajów rozwijających się brakowało danych dotyczących ich PKB per capita, dla 14 z nich także danych dotyczących PNB, a dla 13 krajów - wielkości wartości dodanej brutto. 
Koszty globalnego kryzysu 2008-2009

\begin{tabular}{|c|c|c|c|c|c|c|c|c|}
\hline \multirow[b]{2}{*}{ Metoda } & \multicolumn{2}{|c|}{$\begin{array}{l}\text { PKB per capita } \\
\text { (w USD) }\end{array}$} & \multicolumn{2}{|c|}{$\begin{array}{c}\text { DNB per capita } \\
\text { (w USD) }\end{array}$} & \multicolumn{2}{|c|}{ PKB } & \multicolumn{2}{|c|}{$\begin{array}{c}\text { Wartość dodana } \\
\text { brutto }\end{array}$} \\
\hline & 1 & 2 & 1 & 2 & 1 & 2 & 1 & 2 \\
\hline Albania & $-15,9 \%$ & $-16,7 \%$ & $-16,1 \%$ & $-16,9 \%$ & $-3,1 \%$ & $-3,1 \%$ & $-2,0 \%$ & $-2,0 \%$ \\
\hline Algieria & & & & & $-2,8 \%$ & $-2,8 \%$ & & \\
\hline Andora & $-3,5 \%$ & $-3,8 \%$ & $-3,5 \%$ & $-3,8 \%$ & $-3,8 \%$ & $-3,8 \%$ & $-4,7 \%$ & $-4,6 \%$ \\
\hline Argentyna & $21,6 \%$ & $20,3 \%$ & $20,4 \%$ & $18,9 \%$ & $2,3 \%$ & $2,2 \%$ & $2,1 \%$ & $2,1 \%$ \\
\hline Australia & & & & & $-3,5 \%$ & $-3,5 \%$ & & \\
\hline Austria & $-8,2 \%$ & $-8,9 \%$ & $-8,1 \%$ & $-8,7 \%$ & $-6,7 \%$ & $-6,7 \%$ & $-7,1 \%$ & $-7,1 \%$ \\
\hline Belgia & $-8,9 \%$ & $-9,3 \%$ & $-8,7 \%$ & $-9,2 \%$ & $-6,1 \%$ & $-6,1 \%$ & $-5,8 \%$ & $-5,8 \%$ \\
\hline Białoruś & $-8,8 \%$ & $-14,2 \%$ & $-9,8 \%$ & $-15,3 \%$ & $-3,9 \%$ & $-4,1 \%$ & $-0,3 \%$ & $-0,5 \%$ \\
\hline Boliwia & $20,2 \%$ & $20,0 \%$ & $18,0 \%$ & $17,8 \%$ & $2,9 \%$ & $2,9 \%$ & $3,8 \%$ & $3,8 \%$ \\
\hline $\begin{array}{l}\text { Bośnia i Hercego- } \\
\text { wina }\end{array}$ & $-11,7 \%$ & $-13,0 \%$ & $-13,9 \%$ & $-15,0 \%$ & $0,1 \%$ & $-0,1 \%$ & $0,8 \%$ & $0,8 \%$ \\
\hline Botswana & & & & & $-12,2 \%$ & $-11,9 \%$ & & \\
\hline Brazylia & $7,1 \%$ & $5,9 \%$ & $7,1 \%$ & $6,0 \%$ & $-7,8 \%$ & $-7,9 \%$ & $-1,1 \%$ & $-1,1 \%$ \\
\hline Bułgaria & $-11,5 \%$ & $-12,7 \%$ & $-9,0 \%$ & $-10,8 \%$ & $-9,2 \%$ & $-9,2 \%$ & $-6,8 \%$ & $-6,9 \%$ \\
\hline Chile & $-13,4 \%$ & $-13,1 \%$ & $-9,6 \%$ & $-9,9 \%$ & $-5,1 \%$ & $-5,1 \%$ & $-5,2 \%$ & $-5,2 \%$ \\
\hline Chiny & $12,4 \%$ & $12,4 \%$ & $11,2 \%$ & $11,0 \%$ & $-1,1 \%$ & $-1,1 \%$ & $-0,6 \%$ & $-0,6 \%$ \\
\hline Chorwacja & $-9,5 \%$ & $-10,8 \%$ & $-10,0 \%$ & $-11,2 \%$ & $-10,3 \%$ & $-10,2 \%$ & $-8,3 \%$ & $-8,3 \%$ \\
\hline Cypr & $-7,9 \%$ & $-8,9 \%$ & $-3,8 \%$ & $-4,4 \%$ & $-5,9 \%$ & $-5,9 \%$ & $-5,9 \%$ & $-5,8 \%$ \\
\hline Czarnogóra & $-16,7 \%$ & $-18,0 \%$ & $-15,1 \%$ & $-16,4 \%$ & $-8,3 \%$ & $-8,5 \%$ & $-5,2 \%$ & $-5,6 \%$ \\
\hline Czechy & $-11,3 \%$ & $-13,5 \%$ & $-8,4 \%$ & $-11,5 \%$ & $-8,5 \%$ & $-8,4 \%$ & $-9,0 \%$ & $-9,0 \%$ \\
\hline Dania & $-10,8 \%$ & $-11,3 \%$ & $-9,9 \%$ & $-10,3 \%$ & $6,1 \%$ & $6,2 \%$ & $-8,0 \%$ & $-7,9 \%$ \\
\hline Egipt & & & & & $-0,7 \%$ & $-0,7 \%$ & & \\
\hline Estonia & $-35,8 \%$ & $-34,0 \%$ & $-31,2 \%$ & $-30,1 \%$ & $-31,3 \%$ & $-29,0 \%$ & $-33,8 \%$ & $-31,3 \%$ \\
\hline Etiopia & & & & & $8,6 \%$ & $8,7 \%$ & & \\
\hline Finlandia & $-15,5 \%$ & $-16,0 \%$ & $-15,8 \%$ & $-16,3 \%$ & $-14,0 \%$ & $-13,7 \%$ & $-16,2 \%$ & $-15,8 \%$ \\
\hline Francja & $-8,8 \%$ & $-9,3 \%$ & $-9,3 \%$ & $-9,7 \%$ & $-7,0 \%$ & $-6,9 \%$ & $-6,7 \%$ & $-6,6 \%$ \\
\hline Grecja & $-10,5 \%$ & $-10,9 \%$ & $-9,3 \%$ & $-9,7 \%$ & $-8,7 \%$ & $-8,6 \%$ & $-8,3 \%$ & $-8,2 \%$ \\
\hline Gwatemala & & & $-4,8 \%$ & $-5,4 \%$ & $-3,8 \%$ & $-3,8 \%$ & $-1,9 \%$ & $-1,9 \%$ \\
\hline Hiszpania & $-15,3 \%$ & $-15,4 \%$ & $-15,0 \%$ & $-15,1 \%$ & $-10,1 \%$ & $-9,9 \%$ & $-9,4 \%$ & $-9,3 \%$ \\
\hline Holandia & $-11,0 \%$ & $-11,6 \%$ & $-15,4 \%$ & $-15,5 \%$ & $-7,1 \%$ & $-7,1 \%$ & $-6,8 \%$ & $-6,7 \%$ \\
\hline Honduras & $-0,4 \%$ & $-0,6 \%$ & $-0,7 \%$ & $-0,9 \%$ & $-6,2 \%$ & $-6,2 \%$ & $-5,8 \%$ & $-5,8 \%$ \\
\hline Hong Kong & $-0,9 \%$ & $-1,0 \%$ & $-1,0 \%$ & $-1,2 \%$ & $-7,7 \%$ & $-7,6 \%$ & $-7,0 \%$ & $-6,9 \%$ \\
\hline Indie & $-12,6 \%$ & $-12,3 \%$ & $-12,4 \%$ & $-12,1 \%$ & $-1,3 \%$ & $-1,3 \%$ & $-1,7 \%$ & $-1,7 \%$ \\
\hline Indonezja & $11,1 \%$ & $11,1 \%$ & $14,1 \%$ & $13,9 \%$ & $5,1 \%$ & $5,2 \%$ & $5,2 \%$ & $5,2 \%$ \\
\hline Irlandia & $-34,7 \%$ & $-32,3 \%$ & $-37,3 \%$ & $-34,7 \%$ & $-23,0 \%$ & $-21,7 \%$ & $-23,0 \%$ & $-21,7 \%$ \\
\hline Islandia & $-61,9 \%$ & $-52,5 \%$ & $-65,1 \%$ & $-54,7 \%$ & $-14,5 \%$ & $-14,1 \%$ & $-16,5 \%$ & $-15,9 \%$ \\
\hline Japonia & $15,2 \%$ & $15,6 \%$ & $14,1 \%$ & $14,4 \%$ & $-8,7 \%$ & $-8,5 \%$ & $-7,8 \%$ & $-7,7 \%$ \\
\hline Kanada & $-20,5 \%$ & $-20,0 \%$ & $-21,0 \%$ & $-20,5 \%$ & $-8,2 \%$ & $-8,0 \%$ & $-8,7 \%$ & $-8,6 \%$ \\
\hline Kenia & & & & & $-3,3 \%$ & $-3,3 \%$ & & \\
\hline Kolumbia & $0,5 \%$ & $-0,7 \%$ & $1,2 \%$ & $0,3 \%$ & $-3,7 \%$ & $-3,6 \%$ & $-2,8 \%$ & $-2,8 \%$ \\
\hline Korea Południowa & & & & & $-6,4 \%$ & $-6,3 \%$ & & \\
\hline Kostaryka & $-1,9 \%$ & $-2,4 \%$ & $-2,1 \%$ & $-2,7 \%$ & $-8,8 \%$ & $-8,7 \%$ & $-8,6 \%$ & $-8,5 \%$ \\
\hline Lichtenstein & $-8,2 \%$ & $-8,2 \%$ & $4,2 \%$ & $4,2 \%$ & $-14,8 \%$ & $-14,3 \%$ & $-15,2 \%$ & $-14,7 \%$ \\
\hline Litwa & $-25,5 \%$ & $-27,5 \%$ & $-20,8 \%$ & $-22,8 \%$ & $-23,5 \%$ & $-22,8 \%$ & $-23,6 \%$ & $-22,9 \%$ \\
\hline
\end{tabular}




\begin{tabular}{|c|c|c|c|c|c|c|c|c|}
\hline Luksemburg & $-15,5 \%$ & $-15,9 \%$ & $-24,4 \%$ & $-23,7 \%$ & $-12,1 \%$ & $-11,8 \%$ & $-11,5 \%$ & $-11,3 \%$ \\
\hline Lotwa & $-34,0 \%$ & $-34,1 \%$ & $-25,3 \%$ & $-26,1 \%$ & $-35,0 \%$ & $-32,4 \%$ & $-31,7 \%$ & $-29,6 \%$ \\
\hline Macedonia & $1,4 \%$ & $0,2 \%$ & $5,5 \%$ & $3,8 \%$ & $-1,6 \%$ & $-1,7 \%$ & $-1,5 \%$ & $-1,6 \%$ \\
\hline Malawi & & & & & $8,8 \%$ & $9,0 \%$ & & \\
\hline Malezja & $-5,6 \%$ & $-7,8 \%$ & $-7,5 \%$ & $-9,5 \%$ & $-5,4 \%$ & $-5,4 \%$ & $-5,4 \%$ & $-5,4 \%$ \\
\hline Malta & $-7,6 \%$ & $-8,1 \%$ & $-9,5 \%$ & $-10,0 \%$ & $-4,9 \%$ & $-4,9 \%$ & $-4,4 \%$ & $-4,4 \%$ \\
\hline Maroko & & & & & $-8,9 \%$ & $-9,0 \%$ & & \\
\hline Meksyk & $-28,2 \%$ & $-27,6 \%$ & $-28,1 \%$ & $-27,6 \%$ & $-11,2 \%$ & $-11,1 \%$ & $-12,9 \%$ & $-12,7 \%$ \\
\hline Mołdawia & $7,6 \%$ & $2,8 \%$ & $8,3 \%$ & $3,8 \%$ & $-5,3 \%$ & $-5,7 \%$ & $-4,6 \%$ & $-5,3 \%$ \\
\hline Monako & $-11,3 \%$ & $-11,6 \%$ & $-11,3 \%$ & $-11,6 \%$ & $-9,5 \%$ & $-9,3 \%$ & $-9,5 \%$ & $-9,3 \%$ \\
\hline Namibia & & & & & $-6,4 \%$ & $-6,3 \%$ & & \\
\hline Niemcy & $-7,4 \%$ & $-8,0 \%$ & $-8,2 \%$ & $-8,7 \%$ & $-6,9 \%$ & $-6,8 \%$ & $-7,8 \%$ & $-7,7 \%$ \\
\hline Nigeria & & & & & $-0,3 \%$ & $-0,3 \%$ & & \\
\hline Norwegia & $-17,7 \%$ & $-18,8 \%$ & $-18,0 \%$ & $-19,1 \%$ & $-5,4 \%$ & $-5,3 \%$ & $-4,3 \%$ & $-4,3 \%$ \\
\hline Peru & & & $10,2 \%$ & $9,2 \%$ & $2,5 \%$ & $2,3 \%$ & $2,2 \%$ & $2,1 \%$ \\
\hline Polska & $-13,7 \%$ & $-17,1 \%$ & $-12,5 \%$ & $-16,5 \%$ & $-1,6 \%$ & $-1,6 \%$ & $-2,4 \%$ & $-2,5 \%$ \\
\hline Portugalia & $-11,3 \%$ & $-11,6 \%$ & $-11,1 \%$ & $-11,4 \%$ & $-6,6 \%$ & $-6,5 \%$ & $-6,0 \%$ & $-5,9 \%$ \\
\hline $\begin{array}{l}\text { Republika Połud- } \\
\text { niowej Afryki }\end{array}$ & & & & & $-5,3 \%$ & $-5,3 \%$ & & \\
\hline Rumunia & $-30,3 \%$ & $-31,1 \%$ & $-27,6 \%$ & $-28,6 \%$ & $-7,2 \%$ & $-7,6 \%$ & $-2,4 \%$ & $-2,7 \%$ \\
\hline Salvador & $-8,0 \%$ & $-8,3 \%$ & $-7,8 \%$ & $-8,1 \%$ & $-6,8 \%$ & $-6,8 \%$ & $-6,8 \%$ & $-6,7 \%$ \\
\hline San Marino & $-12,3 \%$ & $-12,6 \%$ & $-12,0 \%$ & $-12,3 \%$ & $-14,8 \%$ & $-14,6 \%$ & $-14,4 \%$ & $-13,9 \%$ \\
\hline Serbia & $-7,0 \%$ & $-10,0 \%$ & $-6,1 \%$ & $-9,3 \%$ & $-3,7 \%$ & $-3,9 \%$ & $-2,0 \%$ & $-2,2 \%$ \\
\hline Singapur & $-9,3 \%$ & $-9,6 \%$ & $-5,1 \%$ & $-5,9 \%$ & $-10,9 \%$ & $-10,6 \%$ & $-8,7 \%$ & $-8,6 \%$ \\
\hline Słowacja & $-7,4 \%$ & $-9,4 \%$ & $-5,2 \%$ & $-7,1 \%$ & $-8,3 \%$ & $-8,4 \%$ & $-9,9 \%$ & $-10,2 \%$ \\
\hline Słowenia & $-11,4 \%$ & $-12,4 \%$ & $-10,9 \%$ & $-11,8 \%$ & $-12,7 \%$ & $-12,6 \%$ & $-12,8 \%$ & $-12,7 \%$ \\
\hline Stany Zjednoczone & $-9,3 \%$ & $-9,1 \%$ & $-10,0 \%$ & $-9,8 \%$ & $-8,0 \%$ & $-7,9 \%$ & $-7,8 \%$ & $-7,7 \%$ \\
\hline Szwajcaria & $3,7 \%$ & $3,0 \%$ & $7,0 \%$ & $7,1 \%$ & $-4,2 \%$ & $-4,2 \%$ & $-4,0 \%$ & $-4,0 \%$ \\
\hline Szwecja & $-22,6 \%$ & $-22,4 \%$ & $-23,5 \%$ & $-23,4 \%$ & $-12,0 \%$ & $-11,7 \%$ & $-12,0 \%$ & $-11,7 \%$ \\
\hline Tajlandia & $-2,2 \%$ & $-2,6 \%$ & $-2,8 \%$ & $-3,2 \%$ & $-6,2 \%$ & $-6,2 \%$ & $-6,2 \%$ & $-6,2 \%$ \\
\hline Tunezja & & & & & $-2,2 \%$ & $-2,2 \%$ & & \\
\hline Turcja & & & & & $-11,7 \%$ & $-11,4 \%$ & $-10,2 \%$ & $-9,9 \%$ \\
\hline Ukraina & $-28,0 \%$ & $-33,5 \%$ & $-28,7 \%$ & $-34,0 \%$ & $-23,2 \%$ & $-22,5 \%$ & $-24,6 \%$ & $-23,7 \%$ \\
\hline Urugwaj & $31,0 \%$ & $31,3 \%$ & $31,4 \%$ & $31,7 \%$ & $8,7 \%$ & $8,8 \%$ & $10,1 \%$ & $10,2 \%$ \\
\hline Wenezuela & $20,9 \%$ & $20,0 \%$ & $18,0 \%$ & $16,8 \%$ & $-4,0 \%$ & $-4,1 \%$ & $-2,4 \%$ & $-2,5 \%$ \\
\hline Węgry & $-24,4 \%$ & $-24,7 \%$ & $-22,5 \%$ & $-22,9 \%$ & $-12,9 \%$ & $-12,6 \%$ & $-26,3 \%$ & $-25,9 \%$ \\
\hline Wielka Brytania & $-36,4 \%$ & $-33,4 \%$ & $-36,0 \%$ & $-33,1 \%$ & $-10,5 \%$ & $-10,3 \%$ & $-10,5 \%$ & $-10,3 \%$ \\
\hline Wietnam & $9,5 \%$ & $8,5 \%$ & $10,3 \%$ & $9,4 \%$ & $-2,6 \%$ & $-2,6 \%$ & $-2,6 \%$ & $-2,6 \%$ \\
\hline Włochy & $-10,8 \%$ & $-11,2 \%$ & $-12,0 \%$ & $-12,1 \%$ & $-9,1 \%$ & $-8,9 \%$ & $-8,8 \%$ & $-8,7 \%$ \\
\hline
\end{tabular}

Źródło: Opracowanie własne na podstawie bazy danych statystycznych OECD: [http://stats.oecd.org/] i IMF [https://www.imf.org/external/data.htm].

W wielu gospodarkach, zwłaszcza państw Ameryki Południowej, na podstawie zastosowanej metody ${ }^{3}$ stwierdzono ujemne koszty kryzysu (tj. odchylenie rzeczywistego od teoretycznego PKB było dodatnie). Przykładowo, w Argentynie PKB per capita oraz DNB per capita odchylenie wyniosło ponad $20 \%$, natomiast w odniesieniu do wartości

${ }^{3} \mathrm{Z}$ uwagi na fakt, że rezultaty uzyskane na bazie metody 1. i metody 2. są podobne, w dalszej części opracowania podaje się wyniki szacowania metodą 1 . 
dodanej brutto i PKB - ponad 2\%. Dla Boliwii były to podobne wyniki, dla Brazylii w granicach 6-7\% oraz minus 6-7\% dla PKB per capita i około - $1 \%$ w wartości dodanej (faktyczne koszty, tj. odchylenie ujemne). Dla gospodarki Stanów Zjednoczonych koszty, liczone w odniesieniu do wszystkich rozpatrywanych wskaźników, wahały się w granicach $-8-10 \%$ (odchylenie ujemne). Chiny w okresie kryzysu rozwijały się nawet szybciej niż wynikałoby to ze średniookresowego trendu rozwojowego, tj. odchylenie dodatnie w granicach $11-12 \%$ w pierwszych dwóch rozpatrywanych wskaźnikach i -0,5 do około $-1 \%$ w dwóch ostatnich. Podobne wyniki uzyskano dla Indii. Stosunkowo wysokie (odchylenie powyżej -20\%) koszty poniosły silnie związane gospodarczo ze Stanami Zjednoczonymi: Meksyk (około -28\% straty per capita) i Kanada (około -20\%). Zróżnicowane wskaźniki odchylenia odnotowano w krajach azjatyckich. Przykładowo, PKB/PNB per capita Indii odchyliły się w latach 2008-2009 o około - $11 \%$ od średniookresowego trendu, natomiast już Indonezja rozwijała się według tego wskaźnika szybciej niż przeciętnie w latach poprzednich (dodatnie 11-12\%). Stosunkowo wysokie koszty poniosły Singapur i Malezja, niskie (około 1\%) Hong Kong.

Porównując wyniki z kolejnych kolumn tabeli 1., można zauważyć, że największe wartości obliczonych kosztów otrzymano, kiedy przedstawiono wartości PKB i DNB per capita $\mathrm{w}$ dolarach amerykańskich. Taki rezultat obliczeń wynika z faktu, że w części krajów dotkniętych kryzysem obowiązywał płynny kurs walutowy i to kurs waluty krajowej osłabiał się zwykle względem dolara w wyniku kryzysu. Wyniki dotyczące kosztów liczonych w walucie krajowej, na przykład przy użyciu produktu krajowego brutto, wskazuja, że w wielu krajach, nawet bez uwzględnienia zmian kursu walutowego, koszty kryzysu były także duże.

Wykres 1. przedstawia empiryczny rozkład (histogram) wielkości kosztów kryzysu. Obrazuje on, że największa liczba krajów (ponad 30) zanotowała straty ponad 5\% PKB, ale nie więcej niż $10 \%$ PKB. W ponad 60 krajach koszty były większe niż $0 \%$ PKB i nie większe niz 15\% PKB. W dziewięciu krajach wzrost PKB był szybszy w czasie kryzysu niż w poprzednich okresach. Należały do nich głównie kraje rozwijające się, ale wśród krajów nieponoszących kosztów kryzysu znalazły się także Argentyna i Dania. W Polsce koszty kryzysu okazały się niewielkie i wyniosły 1,6\% PKB, zgodnie z przyjętą metodologia. 
WYKRES 1.

Rozkład kosztów kryzysu w analizowanych krajach

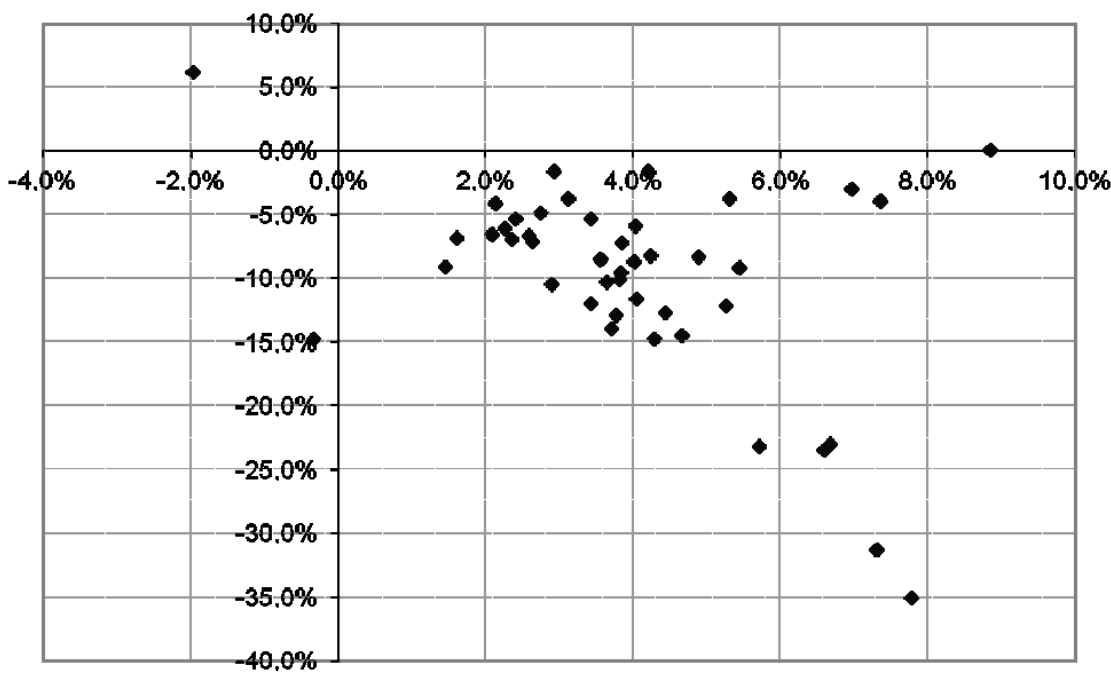

Źródło: Opracowanie własne na podstawie bazy danych statystycznych OECD: [http://stats.oecd.org/] i IMF [https://www.imf.org/external/data.htm].

WYKRES 2.

Koszty kryzysu a DNB per capita na świecie

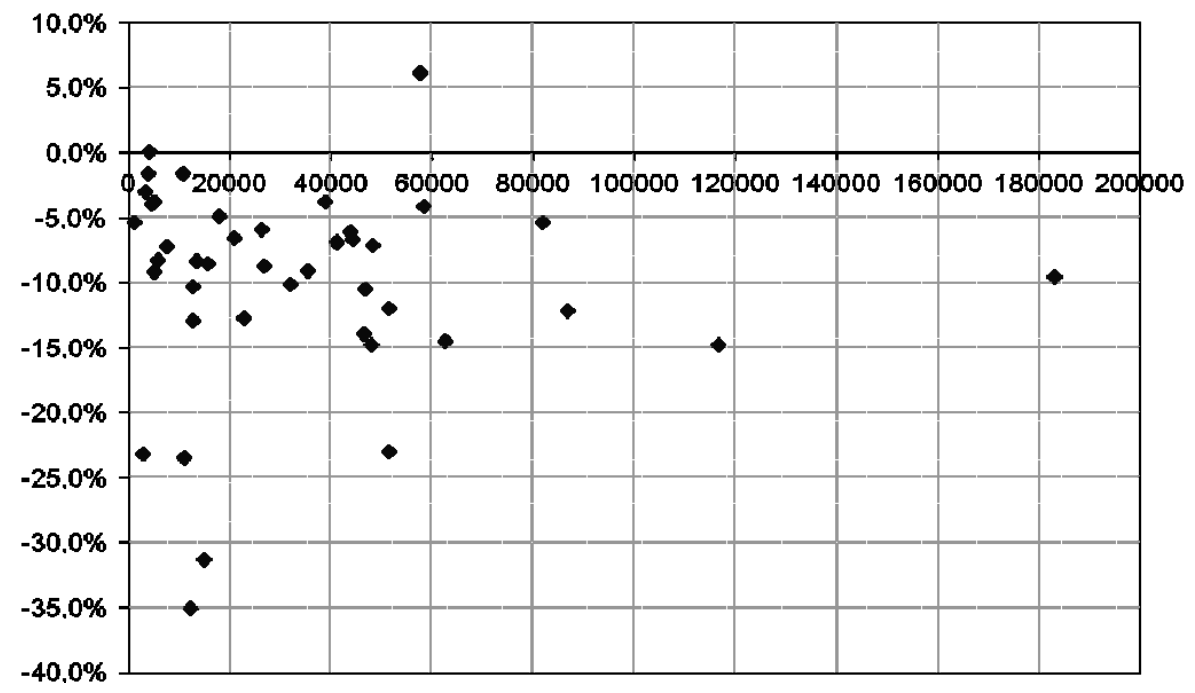

Źródło: Opracowanie własne na podstawie bazy danych statystycznych OECD: [http://stats.oecd.org/] i IMF [https://www.imf.org/external/data.htm]. 
Wykres 2. potwierdza wnioski dotyczące relacji między poziomem bogactwa kraju a kosztami kryzysu. Wykres obrazuje rozkład kosztów kryzysu w poszczególnych krajach z uwzględnieniem zamożności tych krajów przed wystapieniem kryzysu. Wynika z niego, że kryzys dotknął zarówno kraje bogate, jak i kraje biedniejsze. W dużej grupie krajów najbiedniejszych koszty kryzysu okazały się stosunkowo niewielkie, mniejsze niż $5 \%$ PKB. Z drugiej strony, to właśnie w grupie relatywnie biedniejszych krajów (DNB per capita poniżej 20000 USD) znalazły się 4 spośród 5 gospodarek, w których koszty wyniosły ponad $20 \%$.

Jednocześnie należy podkreślić, że kraje europejskie jako grupa poniosły przeciętnie wyższe koszty (liczone w odniesieniu do tych podstawowych wskaźników) niż kraje spoza Europy. Przykładowo, dla Argentyny skumulowane odchylenie wyniosło ponad 20\%, dla: Boliwii około $20 \%$, Brazylii 7\%, Chin niespełna 12,5\%, Indii 9,2\%, Indonezji 11\%, Japonii około 15\%. Natomiast wśród krajów europejskich jedynie trzy kraje nie poniosły kosztów kryzysu, tj.: Szwajcaria, Mołdawia i była Jugosławia. W pozostałych krajach były to koszty od kilkunastu do $-62 \%$ odchylenia w gospodarce Islandii (-38\% w Estonii). Podobne różnice można zauważyć, jeśli chodzi o skutki załamania gospodarczego w Europie, a w innych częściach świata można odnotować, jeżeli porówna się Europe z resztą świata, bazując na pozostałych wskaźnikach wzrostu.

Wykres 3. przedstawia koszty dla Europy na tle innych regionów świata. Zestawiono tu przeciętne koszty PKB per capita dla Europy i Unii Europejskiej z wynikami dla: Ameryki Płd., Ameryki Środkowej, USA, Azji Płd.-Wsch. (policzone jako przeciętne $z$ danych dla właściwych krajów) oraz oddzielnie dla Chin i Japonii. Obrazuje on to, że w Europie (w tym Unii Europejskiej) ujemne odchylenie PKB w okresie kryzysu od 10letniego trendu było szczególnie wysokie. Wyniosło ono dla członków Unii Europejskiej średnio -16,6\%, podczas gdy dla Ameryki Płd. było ono dodatnie (12,6\%), dla USA ujemnie, tj. $-9,3 \%$, nieznacznie ujemne dla Azji Płd.-Wsch. (-1,2\%) oraz dodatnie dla Chin i Japonii (odpowiednio: 12,4 i 15,2\%).

Mniejsze różnice pomiędzy krajami europejskimi a reszta świata można zauważyć dla wyników dotyczących: kosztów PKB, eksportu i importu (wykres 4.). Tylko w krajach Ameryki Płd. odchylenie okazało się dodatnie (1,14\%), niskie ujemne dla Chin i Azji Płd.-Wsch. Tymczasem spadki w handlu zagranicznym - dla odmiany - szczególnie wysokie były dla Chin i Azji Płd.-Wsch. (obniżenie eksportu nastapiło z uwagi na spadek popytu ze strony odbiorców - krajów zachodnich, a import spadł znacząco zwłaszcza w Europie, z odchyleniem do ponad -26\%). Najniższe koszty w handlu zagranicznym również były udziałem Ameryki Płd. Porównując Europę z USA, można zaobserwować, że zarówno jeśli chodzi o koszty PKB, jak i eksportu w Europie, skutki kryzysu okazały się większe niż w USA (koszty PKB w USA to -8\%, a w Unii Europejskiej $-11,5 \%$, koszty eksportu odpowiednio: $-12,3$ i $-22 \%$ ). 
WYKRES 3.

Koszty PKB per capita: Europa a inne regiony świata

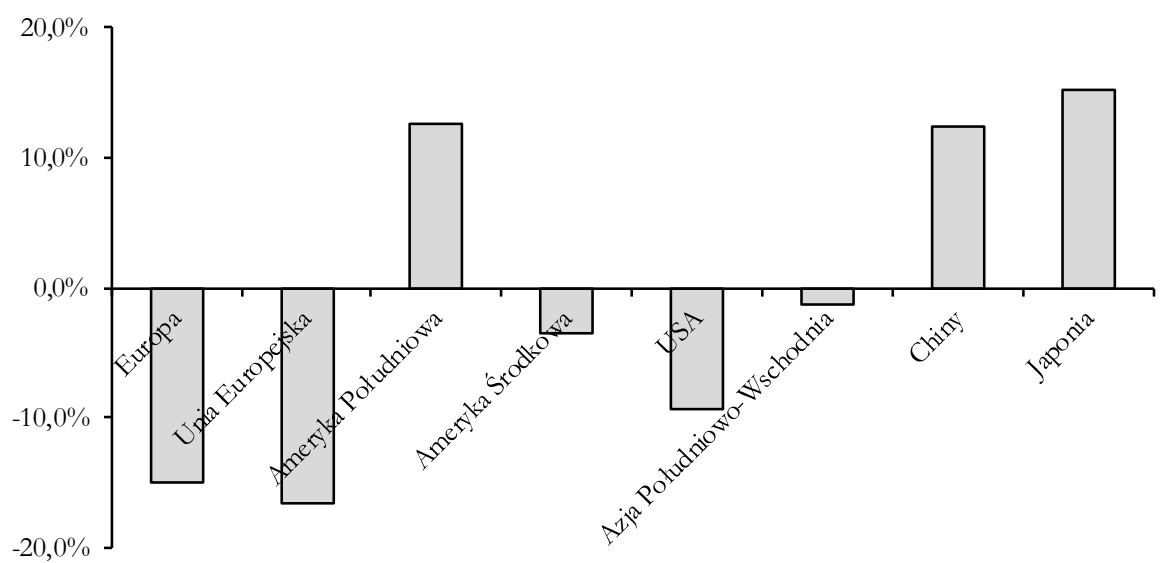

Źródło: Opracowanie własne na podstawie bazy danych statystycznych OECD: [http://stats.oecd.org/] i IMF [https://www.imf.org/external/data.htm].

WYKRES 4.

Koszty PKB, eksportu i importu Europy na tle innych regionów świata

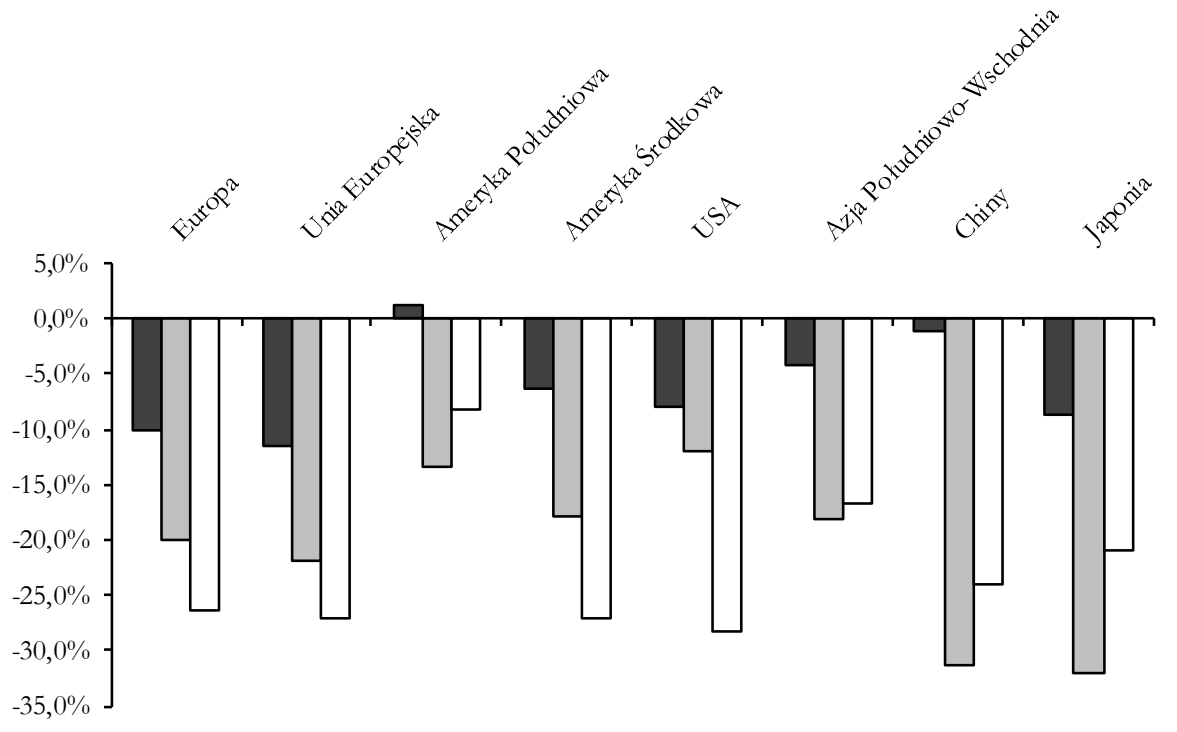

$\square$ koszty PKB $\quad \square$ Koszty eksportu $\quad \square$ Koszty importu

Źródło: Opracowanie własne na podstawie bazy danych statystycznych OECD: [http://stats.oecd.org/] i IMF [https://www.imf.org/external/data.htm]. 
Warto bardziej szczegółowo wziąc pod uwagę same kraje Europy. Koszty kryzysu w 2009 roku, liczone dla PKB, okazały się najwyższe dla niżej rozwiniętych krajów europejskich, krajów bałtyckich, a także dla takich, uzależnionych od sektora bankowego krajów, jak Islandia i Irlandia. Koszty w PKB per capita w 2009 roku były najwyższe dla Ukrainy i wyniosły one $41,4 \%$ (tj. odchylenie procentowe PKB rzeczywistego od teoretycznego równało się $-41,4 \%$ ), dla Bułgarii 28,2\%, Estonii 29,6\%, Węgier 25,6\%, Islandii 35,4\%, Irlandii 25,1\%, Lotwy 34,2\%, Litwy 31,7\%, Rumunii 32,6\%. W krajach strefy euro były one niższe (zwłaszcza w krajach UE-15) i wahały się w granicach 12-15\% (np.: Austria -13,3\%, Belgia -12,4\%, Francja -12,5\%, Niemcy -12,1\%, Włochy -13,2\%). Dla Polski wyniosły one $26,4 \%$ w 2009 roku. Jeśli chodzi o koszty skumulowane, liczone pierwszą metoda, to wahały się one w krajach Europy od 3,5\% w Andorze do prawie $62 \%$ w Islandii. W krajach strefy euro były one stosunkowo niskie, tj. w granicach 8-11\%. (Austria 8,2\%, Belgia 8,9\%, Cypr 7,9\%, Dania 10,8\%, Francja 8,8\%, Niemcy 7,4\%, Holandia 11\%. Najwyższe były dla Estonii, ti. 35,8\% oraz Wielkiej Brytanii 36,4\%. Jak wspomniano, dla trzech krajów rachunek prowadzony według przyjętej metody dał skumulowany wynik dodatni, a więc gospodarki te w okresie kryzysu rozwijały się szybciej niż wynikałoby to z ich dotychczasowego, długookresowego trendu rozwojowego. Przykładowo, dla Szwajcarii różnica między hipotetycznym a rzeczywistym PKB per capita była dodatnia na poziomie $3,7 \%$ oraz dla byłej Jugosławii na poziomie 1,4\%. Korzystny wynik odnotowano także w Mołdawii, tj. odchylenie dodatnie na poziomie 7,6\%.

Stosunkowo niższe koszty kryzysu stwierdzono przy przyjęciu za podstawę liczenia $\mathrm{PKB}$, a nie $\mathrm{PKB}$ - per capita. Tylko w kilku krajach spadek PKB per capita przekraczał koszty PKB; dotyczyło to zwłaszcza krajów o niższym poziomie dochodu na głowę, ze stosunkowo niewielką liczbą ludności, gdzie PKB per capita znacząco spadło, jak: Albania (koszt PKB wyniósł tu $-3,1 \% \mathrm{w}$ stosunku do około $-15 \%$ dla PKB per capita), Białoruś (odpowiednio: -3,8\% i -14,2\%), Bośnia i Hercegowina (odpowiednio: 0,1\% i -11,7\%) Islandia (odpowiednio: $-14 \%$ i około $-60 \%$ ). W Mołdawii sytuacja była odwrotna niż w pozostałej części krajów, a to koszty dodatnie w przypadku PKB per capita to 7,6\% i -5,3\%.

Zróżnicowane wyniki osiagnięto w odniesieniu do wskaźnika wartości dodanej z przeciętnie niższymi odchyleniami wartości tego wskaźnika od przeciętnych z lat poprzednich (różnice rzędu 0,5 do $2 \%$ ) niż w przypadku pozostałych kategorii makroekonomicznych, jednakże podobnym rozkładem wartości oszacowań w przekroju krajów. Największe załamanie wartości dodanej odnotowano w Estonii (-37\%) i na Węgrzech $(-26 \%)$.

Jeśli chodzi o koszty wydatków konsumpcyjnych (wykres 5.), to wahały się one od $-0,3 \%$ w Bośni i Hercegowinie do ponad 37\% w Estonii. W krajach UE-15 nie były najwyższe i wynosiły około 1,5\% (Austria $-1,5 \%$, Belgia $-1,9 \%$, Francja $-4,3 \%$, Niemcy $-1,4 \%$ ). Wśród tych krajów wyższe koszty ponieśli członkowie z Południa, tj.: Włochy, Portugalia czy Grecja (ponad 5\%). W Polsce nie odnotowano spadku w omawianym zakresie, tj. odchylenie wyniosło 0,1\% (dodatnie). W krajach południowej Europy, nienależących do Unii Europejskiej, obniżenie konsumpcji było większe (w Bułgarii i Chorwacji około 14-15\%, Mołdawii 14\%, Czarnogórze 16\%, Rumunii 15\%). Najwyższe koszty, oprócz Estonii (37-procentowy skumulowany spadek konsumpcji w stosunku do trendu), poniosły: Islandia (ponad 30-procentowy spadek) i Lotwa (ponad 40-procentowy). 
W kolejnej kategorii, tj. wartości wydatków rządowych, w przeważającej liczbie krajów odnotowano odchylenie dodatnie w przypadku wydatków rządowych (zgodnie z teorią ekonomii spełniają one rolę automatycznych stabilizatorów koniunktury). Wydatki te wzrosły zwłaszcza w krajach strefy euro: w Austrii o 1,3\%, Francji o 1,6\%, w Niemczech o 3,4\%, na Słowacji o 6,5\%, w Szwecji i Szwajcarii o około 1\%. W Mołdawii odnotowano szczególnie duże odchylenie dodatnie, tj. około 15\%. Wartość tej składowej PKB znacząco jednak spadła w Bułgarii (tj. o około 17\%), Irlandii i na Lotwie, (t). o prawie $13 \%$ ), na Ukrainie (o prawie 15\%).

Najbardziej - co typowe dla okresów dekoniunktury - spadły wydatki inwestycyjne (w tym inwestycje w środki trwałe). W Albanii koszty w tym zakresie wyniosły prawie $-18 \%$, w Chorwacji -16\%, Bośni i Hercegowinie -22\%, Bułgarii ponad -38\%, Finlandii $-33 \%$. W większości krajów strefy euro odchylenie wyniosło minus kilkanaście procent, ale np. w Grecji inwestycje obniżyły się w stosunku do średniej o prawie 30\%. Największe załamanie (podobnie jak w zakresie innych kategorii) odnotowano na Islandii (spadek o 83\%, na Lotwie, tj. o około 60\%, na Litwie było to około 55\%). Podobnie było w krajach Europy Płd. i Wsch. (Czarnogóra -50\%, Rumunia -27\%, Bułgaria -37\%, Serbia $-31 \%$, Ukraina $-53 \%$, Mołdawia -42\%). Jedynym krajem Europy, gdzie inwestycje wzrosły w okresie 2008-2009, była Białoruś (odchylenie dodatnie 2,9\%).

WYKRES 5.

\section{Koszty w poszczególnych składowych PKB (Europa)}

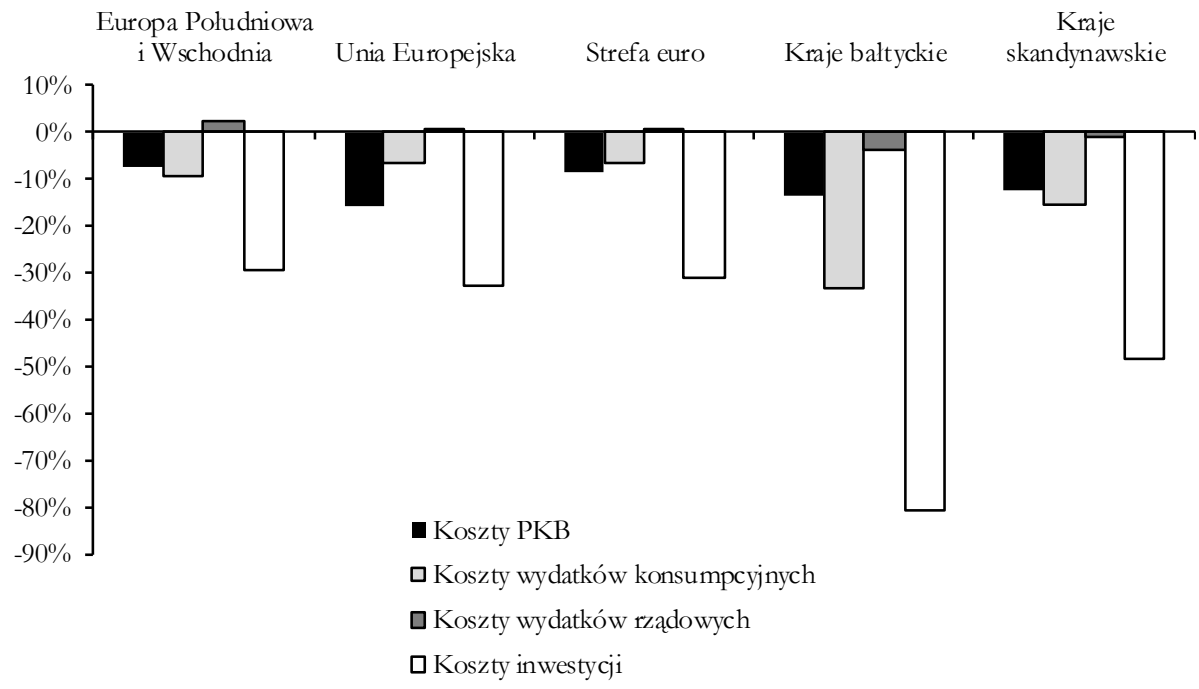

Źródło: Opracowanie własne na podstawie bazy danych statystycznych OECD: [http://stats.oecd.org/] i IMF [https://www.imf.org/external/data.htm].

$\mathrm{Na}$ rysunku 5. przedstawiono szczegółowe wyniki liczenia kosztów kryzysu w obszarze: PKB, wydatków konsumpcyjnych gospodarstw domowych, inwestycji i wydat- 
ków rządowych dla większości krajów Europy (zrezygnowano z pomniejszych gospodarek dla większej przejrzystości rysunku). Jak wynika z powyższego wykresu, największe średnie ujemne odchylenie PKB, łącznie dla lat 2008 i 2009 od wartości wynikającej z długookresowego trendu, odnotowano w krajach bałtyckich (około -12\%), najmniejsze (tj. - 6,7\%) w krajach Europy Płd. i Wsch. spoza Unii Europejskiej (do których zaliczono: Albanię, Białoruś, Chorwację, Bośnię i Hercegowinę, była Jugosławię, Serbię, Czarnogórę, Mołdawię i Ukrainę). Przeciętne odchylenie w krajach strefy euro wyniosło $-8,6 \%$. Podobnie w grupie krajów bałtyckich największy był spadek wydatków konsumpcyjnych gospodarstw domowych (ponad -33\%), średni w krajach skandynawskich (około $-15 \%$ ), najniższy w strefie euro $(-6,7 \%)$. Wydatki rządowe wykazały dodatnie (we wszystkich grupach, oprócz krajów bałtyckich) odchylenie od wartości teoretycznych (zgodnie z teoria jako automatyczne stabilizatory). Dla krajów Europy Płd. i Wsch. odchylenie to wyniosło 2,3\%, a dla Unii Europejskiej 0,7\%.

Bardzo wysokie okazaly się spadki w zakresie wydatków inwestycyjnych, które sięgnęły $80 \%$ w krajach bałtyckich (z Estonia -84,3\%, Lotwą w okolicach 70\% i Litwa około $60 \%$ ujemnego odchylenia od średniookresowego trendu), 48\% w krajach skandynawskich i 33\% przeciętnie w Unii Europejskiej.

Odnotowano także znaczące załamanie w handlu zagranicznym (wykres 6.), zwłaszcza w imporcie ujemne odchylenie od wartości wynikających z 10-letniego trendu było bardzo duże: około $-26 \%$ przeciętnie w Europie (około $21 \mathrm{w}$ eksporcie), w strefie euro -24\% (i 22,7\% w eksporcie), dla krajów Europy Środkowej i Wschodniej, spoza Unii Europejskiej, około $-39 \%$ (i prawie 32\%).

WYKRES 6.

Koszty importu i eksportu w przekroju grup krajów europejskich

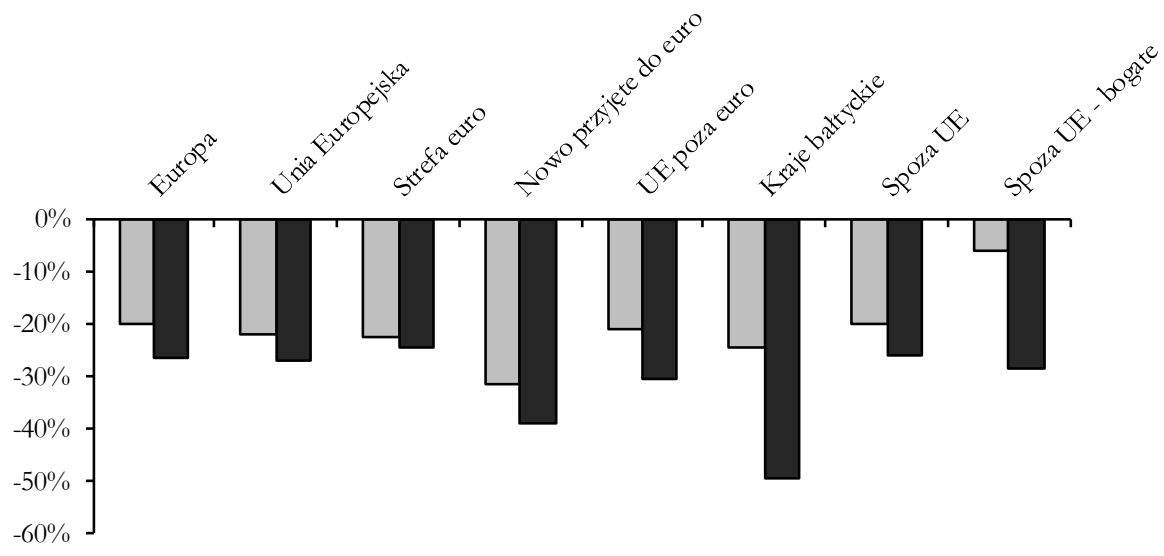

口 Koszty eksportu $\quad$ Koszty importu

Źródło: Opracowanie własne na podstawie bazy danych statystycznych OECD:

[http://stats.oecd.org/] i IMF [https://www.imf.org/external/data.htm]. 
Warto przejść teraz do liczenia kosztów kryzysu w poszczególnych branżach (produkcja i usługi), rozpoczynając od ogólnego spojrzenia na regiony świata. Wykres 7. wskazuje, że spadki w przekroju gałęzi w poszczególnych regionach były zróżnicowane. Produkcja rolnicza wykazała największe odchylenie ujemne od 10-letniego trendu w USA (-7,5\%), niższe w krajach Ameryki Płd., natomiast w Europie (w tym Unii Europejskiej) produkcja rolnicza rozwijała się nawet szybciej niż przed kryzysem (dodatnie odchylenie o wartości 5,6\%). Najszybciej w okresie kryzysu rozwijała się produkcja rolnicza w Chinach (ponad 13-procentowe odchylenie dodatnie), w pozostałych regionach świata okazała się ona ujemna (w USA -7,5\%), podobnie w Japonii. Przemysł wydobywczy na całym świecie zanotował największe spadki o różnej skali: największe w Unii Europejskiej (odchylenie -16,4\%), w Japonii było to -10,6\%, w USA niespełna 8\%, a w Ameryce Płd. jedynie około 1,5\%. W zakresie przemysłu przetwórczego również najsłabsze wyniki w okresie kryzysu odnotowała Europa (-15,7\%) i ponad -18\% Unia Europejska. W Chinach odchylenie od trendu w tej gałęzi wyniosło jedynie $-3,18 \%$, a w Ameryce Płd. -0,8\%.

Bardziej szczegółowej prezentacji kosztów kryzysu w grupie krajów europejskich w przekroju gałęzi dostarcza wykres 8 .

WYKRES 7.

\section{Rozkład kosztów w poszczególnych branżach produkcyjnych w regionach} świata

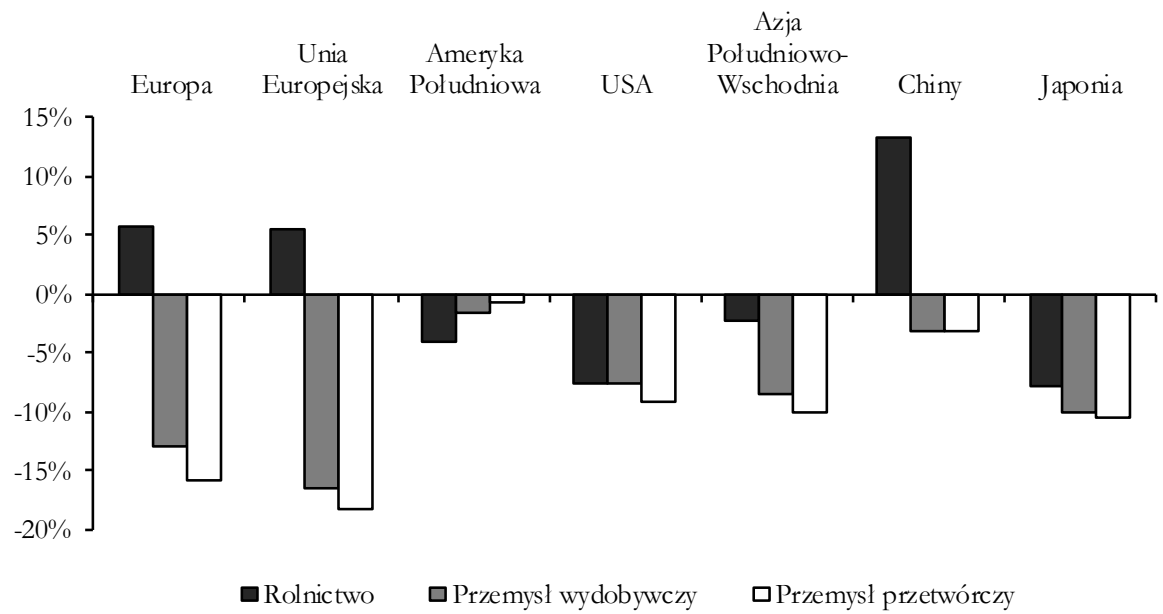

Źródło: Opracowanie własne na podstawie bazy danych statystycznych OECD: [http://stats.oecd.org/] i IMF [https://www.imf.org/external/data.htm]. 
Jak wynika z wykresu 8., spadki w poszczególnych branżach miały zbliżoną skalę w przekroju grup krajów europejskich. Największe koszty można zaobserwować (podobnie jak na całym świecie) w przemyśle wydobywczym. W odniesieniu do tej gałęzi widać ogromny spadek produkcji w krajach nowo przyjętych do strefy euro (tj. po roku 2006), a więc spoza rdzenia tzw. Piętnastki (UE-15) najbogatszych jej członków, oraz w krajach bałtyckich. O takim wyniku zadecydowała obecność w obydwu grupach Estonii, która szczególnie doświadczyła kryzysu. Analogiczne wytłumaczenie wiąże się z przemysłem przetwórczym, gdzie najwyższe koszty poniesiono w krajach bałtyckich oraz nowo przyjętych do euro. Jeśli chodzi o sektor usług, to w ślad za spadkiem konsumpcji gospodarstw domowych handel wewnętrzny uległ najgłębszym spadkom w krajach bałtyckich oraz członkach Unii Europejskiej nienależących do strefy euro.

WYKRES 8.

\section{Spadek produkcji w krajach europejskich w podziale na grupy}

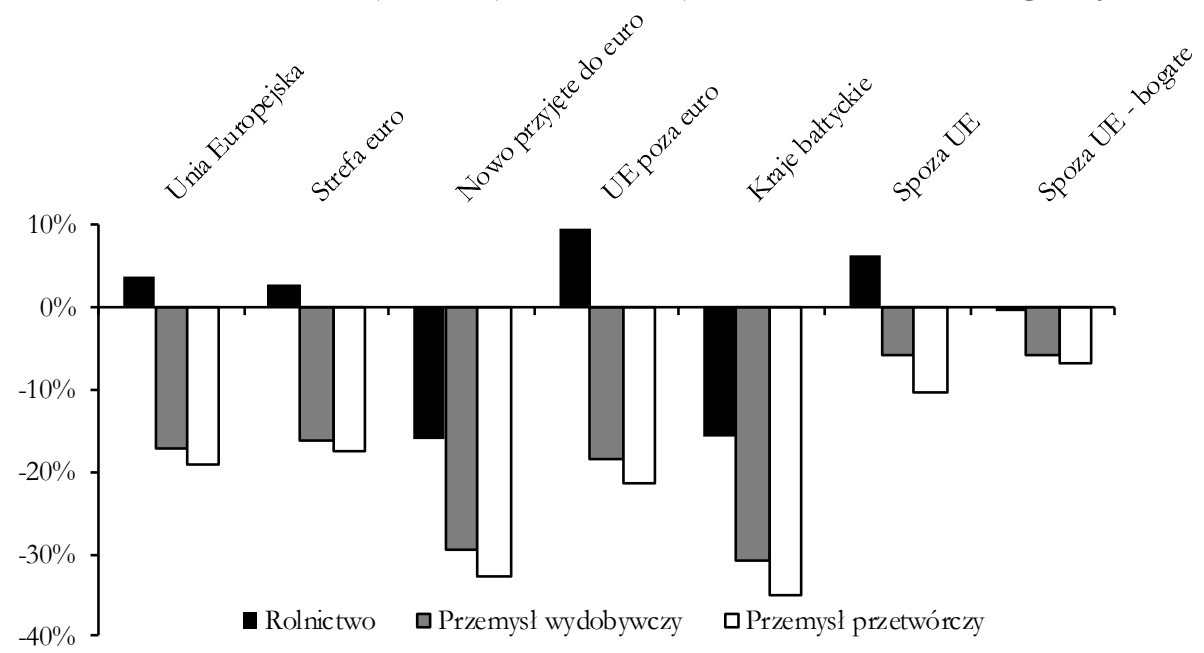

Źródło: Opracowanie własne na podstawie bazy danych statystycznych OECD: [http://stats.oecd.org/] i IMF [https://www.imf.org/external/data.htm].

Ogólnie rzecz biorąc, koszty okazały się wyższe po stronie usług niż produkcji i ujawniły się, zwłaszcza w budownictwie i transporcie, co z całą pewnością stanowiło efekt mnożnikowy schłodzenia koniunktury w sferze produkcji realnej. 
WYKRES 9.

\section{Koszty usług w przekroju grup krajów Europy}

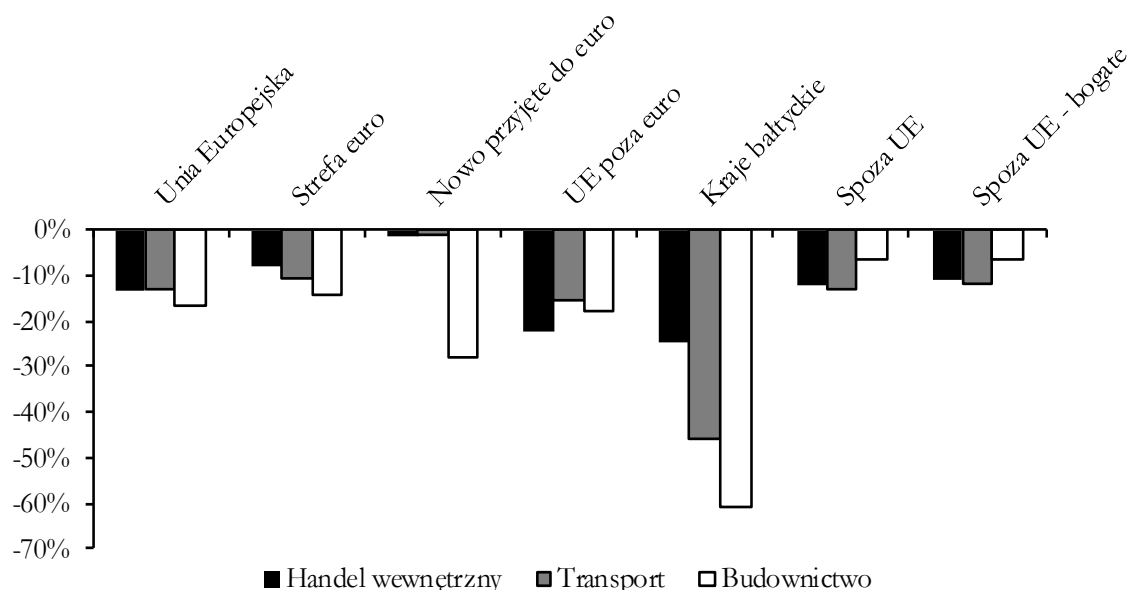

Źródło: Opracowanie własne na podstawie bazy danych statystycznych OECD: [http://stats.oecd.org/] i IMF [https://www.imf.org/external/data.htm].

\section{Podsumowanie}

Badanie zaprezentowane w niniejszym artykule przedstawia koszty kryzysu gospodarczego z lat 2008-2009 dla wybranych krajów z różnych regionów świata i odnoszące się do podstawowych mierników rozwoju gospodarczego, a także poszczególnych składników produktu zagregowanego. W celu uzupełnienia analizy autorzy oszacowali i opisali rozkład kosztów w podziale na główne gałęzie gospodarki, ukazując go zarówno dla wyodrębnionych grup krajów Europy, jak i w przekroju regionów świata. Przeprowadzona analiza pokazuje, że gospodarka europejska (zwłaszcza Unii Europejskiej i strefy euro) została szczególnie silnie - na tle innych rynków światowych - dotknięta skutkami ostatniego kryzysu globalnego (dotyczy to w równej mierze spadków ogólnie, tj. odnotowanych w zagregowanej produkcji, jak i w odniesieniu do konsumpcji i nakładów inwestycyjnych). W sferze eksportu kryzysem najmocniej zostały dotknięte kraje Azji Płd.-Wsch. (w tym: Chiny i Japonia), a przyczyną tego był spadek popytu ze strony rynków krajów zachodnich (Unia Europejska, Stany Zjednoczone). Analiza struktury spadków w międzynarodowym handlu w podziale na gałęzie gospodarki ukazuje, że stosunkowo największe koszty poniosły przy tym (tak samo w rolnictwie, przemyśle przetwórczym i wydobywczym, jak i w branżach usługowych) kraje bałtyckie i kraje zaliczone w tym badaniu do „,nowo przyjętych do strefy euro”. Najwyższe koszty makroekonomiczne objęły przemysł przetwórczy (najbardziej narażony na spadek inwestycji). Zaprezentowane badanie może stanowić punkt wyjścia dalszej, bardziej pogłębionej, analizy koncentrującej się np. na cechach strukturalnych poszczególnych gospodarek narodo- 
wych lub grup krajów jako czynnikach podatności na skutki załamań gospodarczych o zasięgu globalnym.

\section{Literatura}

Aziz J., Caramazza F., Salgado R. 2000 Currency Crises: In Search of Common Elements, „IMF Working Paper”, 00/67.

Barro R. J. 2001 Economic Growth in East Asia Before and After the Financial Crisis, „NBER Working Paper", no. 8330.

Boyd J. H., Kwak S., Smith B. 2005 The Real Output Losses Associated with Modern Banking Crises, ,Journal of Money, Credit, and Banking”, 37.

Dell'Ariccia G., Detragiache E. Rajan R. 2005 The real effect of banking crises, IMF Working Paper, 05/63.

Frydl E.J. 1999 The length and cost of banking crises, IMF Working Paper, 99/30.

Hoggarth G., Reis R., Saporta V. 2002 Costs of banking system instability: some empirical evidence, „Journal of Banking and Finance", 26.

Honohan P., Klingebiel D. 2002 Controlling the Fiscal Costs of Banking Crises, [in:] Managing the Real and Fiscal Effects of Banking Crises, World Bank Discussion Paper, no. 428.

Hutchinson M. M., Noy H. 2005 How Bad are the Twins? Output Costs of Currency and Banking Crises, „Journal of Money”, Credit and Banking, 37.

Kroszner R. S., Laeven L., Klingebiel D. 2007 Banking crises, financial dependence, and growth, „Journal of Financial Economics", 84.

Laeven L., Valencia F. 2010 Banking Crisis Database, World Bank.

Międzynarodowy Fundusz Walutowy 1998 Financial Crises and Indicators of V ulnerability, World Economic Outlook, Ch. 4, maj.

Międzynarodowy Fundusz Walutowy 1999 From Crisis to Recovery In the Emerging Market Economics, World Economic Outlook, Ch. 2, październik.

Serwa D. 2010 Larger crises cost more: Impact of banking sector instability on output growth, „Journal of International Money and Finance”, 29. 